\title{
From Clothing Rations to Fast Fashion: Utilising Regenerated Protein Fibres to Alleviate Pressures on Mass Production
}

\author{
Marie Stenton ${ }^{1}$, Veronika Kapsali ${ }^{1}\left(\mathbb{D}\right.$, Richard S. Blackburn ${ }^{2}$ (D) and Joseph A. Houghton ${ }^{2, *(D)}$ \\ 1 London College of Fashion, University of the Arts London, London SW1P 4JU, UK; \\ m.stenton0620191@fashion.arts.ac.uk (M.S.); veronika.kapsali@fashion.arts.ac.uk (V.K.) \\ 2 School of Design, University of Leeds, Leeds LS2 9JT, UK; r.s.blackburn@leeds.ac.uk \\ * Correspondence: j.a.houghton@leeds.ac.uk
}

check for

updates

Citation: Stenton, M.; Kapsali, V.; Blackburn, R.S.; Houghton, J.A. From Clothing Rations to Fast Fashion:

Utilising Regenerated Protein Fibres to Alleviate Pressures on Mass Production. Energies 2021, 14, 5654. https://doi.org/10.3390/en14185654

Academic Editors:

Arkadiusz Piwowar and

Maciej Dzikuć

Received: 23 August 2021

Accepted: 6 September 2021

Published: 8 September 2021

Publisher's Note: MDPI stays neutral with regard to jurisdictional claims in published maps and institutional affiliations.

Copyright: (C) 2021 by the authors. Licensee MDPI, Basel, Switzerland. This article is an open access article distributed under the terms and conditions of the Creative Commons Attribution (CC BY) license (https:/ / creativecommons.org/licenses/by/ $4.0 /)$.

\begin{abstract}
Sustainable methods of practice within the fashion and textile industry (FTI) often strive to employ a circular economy that aims to eliminate waste through the continual use of resources. Complex problems such as waste, consumption, and overproduction are heavily intertwined; the main aim of this paper is to report on research focused on re-examining the potential of food waste streams as a commercially viable and circular source of raw materials for the FTI. Herein, regenerated protein fibres (RPFs) from food production waste streams rich in protein have been chosen as the main topic of focus. RPFs have a rich and relevant history from a local manufacturing perspective during wartime and post-war clothing rationing (1941-1949) in the UK. RPFs were used to meet civilian needs for wool-based textiles as part of a wider series of 'make do and mend' strategies designed to manage the consumption of new textile products. However, RPFs demonstrated inferior quality in terms of durability when compared to wool-based textiles, a significant contributing factor to the consequent commercial phasing out of RPFs. In today's take-make-waste model, the FTI landscape can be defined by speed, from slow (high-quality materials and construction, long-lasting products) to fast (seasonal, disposable, low-quality materials and construction), the latter infamous for dire environmental impacts. A key objective of this research is to review the association of quality and longevity within the context of a local and circular fashion economy in which textile quality and lifecycle analysis are holistically matched to the longevity of the textile, garment, or product to reduce waste across the supply chain.
\end{abstract}

Keywords: waste; regenerated protein fibres; regenerated fibres; textiles; speedcycles; consumption; quality; circular economy; man-made fibres; textile history

\section{Introduction}

The time needed to reverse the effects of climate change is quickly running out. This research brings together a necessary range of literary sources and disciplinary expertise to analyse the bigger picture surrounding the development and consumption of sustainable new materials and their impact upon the environment. Regenerated protein fibres (RPFs) have been chosen as a primary example due to the unexpected synergy between the modern climate of overproduction in the textile industry and the political crisis and material shortage experienced during the age in which RPFs, historically known as azlons, were developed. Together, these two issues provide a refreshing outlook for the exploration of reducing locally produced waste volumes while relieving pressure on natural and synthetic fibres through increases in production.

The fashion industry is responsible for $10 \%$ of worldwide GHG emissions, including $4 \%$ of global $\mathrm{CO}_{2}$ emissions, and this is on-trend to increase to $25 \%$ of global GHG emissions by 2050 [1-3]. When compared to sectors that are typically considered heavily polluting, such as aviation and maritime shipping, the fashion industry exhibits a much larger GHG emission (10\% as opposed to $4.4 \%$ for aviation and maritime shipping) [3]. Not only this, but a large proportion of the aviation and maritime shipping is devoted to moving textiles, 
raw materials for the production of textiles, and finished clothing articles around the world, increasing the carbon footprint of the fashion industry further. With the current growth of the fashion sector, it is predicted that freight use will as much as triple by 2040 [3]. The fashion industry is also one of the largest producers of wastewater in the world, contributing $20 \%$ of wastewater produced globally $[2,4,5]$.

The burden of items from the fashion industry at the end of consumer use cannot be ignored, with $85 \%$ of all textiles ending up in landfills every year rather than being recycled or degraded back into the environment [3]. For the clothing market alone, this equates to USD 400 billion of clothing being wasted annually [6], which is being driven by a rapid increase in the production and consumption of textiles, with the textile industry doubling in the last 20 years and average global textile purchasing increasing from 7 to $13 \mathrm{~kg} / \mathrm{year}$ per capita [7]. This average is heavily skewed towards the western world, with the USA purchasing $37 \mathrm{~kg}$ /capita/year, Australia $27 \mathrm{~kg}$ and Western Europe $22 \mathrm{~kg}$, while Africa, India and Southern Asia exhibit an annual purchasing of just $5 \mathrm{~kg} /$ year per capita [8]. Taking Australia as an example, the average Australian purchases $27 \mathrm{~kg}$ of new textiles per year and discards an average of $23 \mathrm{~kg}$ to landfill within the same amount of time [9].

With fast fashion and a growing global population, along with increased concern over the sustainability and traceability of products, finding and developing novel methods for textile production whilst reducing excess waste is an ever more prevalent challenge [10]. Although feedstocks for materials is currently a major problem, the issue of demand must also be considered. Currently, petrochemical-derived fibre use is $62 \%$ of the global total, with cotton at $25 \%$ of this total [11]; phasing out petrochemical-based fibres entirely would put a huge strain on the production of natural resources and would likely lead to further issues centred around the farming of a single raw material, such as cotton. The processing of natural fibres also depends on non-renewable resources, requiring large amounts of chemicals and high use of thermal and electric energy [12,13].

A commonly accepted solution amongst the fashion industry is to 'slow' the fashion cycle and focus on the production of high-quality garments [14]. The interpretation of 'speed' in the fashion industry often relates to the 'use phase' of a product [15] (how long a product is designed to be used) or the 'production speed' (how quickly a product can be delivered from concept to store) [16]. It could be argued, however, that a mixed economy of both slow and fast fashion is necessary to creating an inclusive fashion system capable of reflecting the genuine needs of consumers and that a change in consumption habits and consumer mindsets is the key to the sustainable implementation of such a system. As stated by Kendall [17], "We're caught between two economies of time ... one fast and furious, the other slow and steady. Industry need not design what it makes to be durable beyond a certain amount of time, any more than nature does."

The concept of 'speedcycles' was initially developed through the Circular Design Speeds project as part of Mistra Future Fashion Design Theme research (2015-2019). The aim was to develop 'ultra-fast' and 'superslow' design prototypes for different circular fashion scenarios using collaborative and multidisciplinary research methods [18]. Although the design and manufacture of durable and long-lasting clothing have historically been a priority of the fashion industry, the concept of slow fashion has been promoted in recent years as a new alternative to fast fashion. However, as discussed by Goldsworthy [16], the problem with only focusing on a slow speedcycle is that without a shift in both cultural attitudes and garment collection schemes, many of these items will still end up in landfills without fulfilling their full potential. Such concepts, while admirable in their efforts, may reduce focus to only part of the system and are too simplistic to solve the larger issues at hand. There is also a range of socio-economic limitations to the switch to a completely slow fashion market, which tends to be less affordable and may be unattainable to a range of consumer demographics. 
The creation of RPFs from food industry waste could offer a new perspective to our interpretation of fast and slow speedcycles through the design of textile materials that require a low input of resources and are created to last a specified amount of time. Drawing inspiration from the textiles market during wartime, this paper explores the necessary means to alleviating pressures on mass consumption whilst still offering an ethical and 'affordable' fast fashion model alongside a slow fashion model. This research also aims to identify any gaps in both the historical and contemporary data surrounding the production of RPFs from a sustainability viewpoint, thus outlining opportunities for further investigation.

\section{Methods}

This paper is based on a literature review interconnecting design, science, and industry to explore how textile materials can be created from food industry waste to help tackle complex problems such as waste and overconsumption in the fashion industry. The authors used regenerated protein fibres (RPFs) as a case study to compare how the approach taken to feedstock shortages during the world wars could be analogous with these more contemporary issues. The research question is to explore how RPFs from food industry waste offer a new perspective on our interpretation of fast and slow speedcycles whilst alleviating pressures on mass consumption. The approach used involved an initial planning stage, during which the research question was outlined; a design phase, where the authors delegated areas of research based on expertise; a preparation phase, beginning with widescope literature (which was narrowed as the process continued); a data collection phase, where the relevant information was collated from the literature search; an analysis phase, in which conclusions were drawn based on critical analysis of the information; and, finally, a reporting phase, during which the authors wrote their findings and opinions into the finalised review.

A range of both historical and contemporary literary sources was reflected upon to draw comparisons between economic and government solutions surrounding the consumption of resources in times of need. An exhaustive review of the relevant patents was conducted to ensure that an accurate picture of the history of RPF production was obtained. In the context of taking an interdisciplinary approach, using a wide range of resources was necessary to the critical analysis of various methods of complex problem solving from design, scientific, political, sociological, economic and consumer perspectives.

The research involved the analysis of both quantitative and qualitative data to gain a deeper understanding of the complexities behind the research question. Quantitative data was taken from reputable sources such as reports issued by the United Nations (UN) and the Waste and Resource Action Programme (WRAP). Qualitative data were obtained through a systematic review of the relevant literature, including from scientific journals as well as reputable, high-quality grey literature, including industrial and parliamentary reports by companies such as the Ellen MacArthur Foundation. Recent consumer surveys were also analysed to underpin the motivations of switching behaviours towards sustainable fashion and shopping habits. Where data were obtained from grey literature, efforts were made to corroborate the information from two different sources to increase its validity. Keywords such as 'regenerated protein fibres', 'fashion speedcycles', and 'circular economy' were used as a starting point for finding relevant literature. Once a literature resource was found, the abstract or executive summary was examined, and if found to be of interest, the remainder of the relevant information was read and obtained.

This wide combination of sources provides a more holistic account of both the economic and societal pressures that must be considered when transitioning to a circular economy and a more sustainable future. The authors of this paper have each used their disciplinary backgrounds to explore the context of the research from different perspectives, which were then brought together to create a unique and collaborative viewpoint. The interdisciplinary approach taken combines that of an experienced fashion and textiles practitioner and researcher with that of a chartered environmentalist in the field of green 
chemistry. Alongside these fields, socio-economic and historical influences upon the subject matter have also been explored to offer a much needed, human-centred perspective on the topic of creating systematic change.

\section{Results}

\subsection{Fibres from Waste Foods}

Food waste represents a crisis of epic proportions for humanity on a global scale and is the focus of several of the SDGs, particularly Goal 12: Responsible Production and Consumption [19-21]. It is estimated that one-third of all food produced on the planet goes to waste, amounting to almost 1.3 billion tonnes annually [22]. A large proportion of this waste is due to harvesting and production, but a recent 2021 report by the UN states that 931 million tonnes of food waste was generated by the retail sector to the home consumer [23], with an economic loss of over USD 400 billion a year [24]. In the UK alone, 9.5 million tonnes of food waste was generated in 2018, a 2021 report by WRAP [25] has estimated, representing a revenue loss of GBP 19 billion and theoretically producing 25 million tonnes of greenhouse gas (GHG) emissions. While there is no direct data for comparing the food waste post-farm gate to pre-farm gate in the UK, WRAP attempted to estimate it through an exhaustive literature review of similar data from other countries and predicted that food loss (both through waste and surplus) pre-farm gate could be as much as 3.6 million tonnes, meaning that this sector could account for more than retail and hospitality combined [25,26].

Hence, there is the potential to address two of the largest issues in the modern world; the excess waste generated through the food processing industry and the environmentally detrimental demand for fibres and materials of the textile industry. The utilisation of food waste as a feedstock for extraction or conversion into fibres would theoretically reduce the amount of waste generated by the food sector while reducing our reliance on petrochemicalderived fibres and the pressure on the overproduction of natural fibres such as wool and cotton.

Although RPFs are the main subject of this paper, textile materials that have been developed from food waste can take many forms. Over the past decade, a resurge of interest in the development of novel and sustainable fibres has led to an extensive expansion of the traditional categories of natural or synthetic fibres, which now include subcategories such as 'bio-based', 'biofabricated', and 'biosynthetic' [27]. Bio-based materials are derived from biomass (organic waste) "that can have undergone physical, chemical or biological treatment and include materials derived from plants, trees, or animals" [28]. Alongside RPFs, bio-based materials such as orange fibre [29] and Piñatex [30] (see Table 1 for more examples) are defining new circular manufacturing systems through the utilisation of food industry waste. Figure 1 demonstrates the different types of fibres that can be created from various sources of food waste.

Table 1. Materials from food waste used in textile applications.

\begin{tabular}{cccccc}
\hline $\begin{array}{c}\text { Brand/Trade } \\
\text { Name }\end{array}$ & Raw Material & $\begin{array}{c}\text { Country of } \\
\text { Origin }\end{array}$ & Material Type & Textile Material & Applicable Industries \\
\hline QMILK & Milk & Germany & $\begin{array}{c}\text { RPF for woven, } \\
\text { knitted and } \\
\text { non-wovens }\end{array}$ & $\begin{array}{c}\text { Lightweight fibre } \\
\text { automotive, medical } \\
\text { and cosmetics }\end{array}$ \\
Orange Fibre & Orange peel & Italy & $\begin{array}{c}\text { Regenerated cellulose } \\
\text { fibre for knitted and } \\
\text { wovens }\end{array}$ & Lightweight fibre & Fashion, textiles \\
\hline
\end{tabular}


Table 1. Cont.

\begin{tabular}{|c|c|c|c|c|c|}
\hline $\begin{array}{l}\text { Brand/Trade } \\
\text { Name }\end{array}$ & Raw Material & $\begin{array}{l}\text { Country of } \\
\text { Origin }\end{array}$ & Material Type & Textile Material & Applicable Industries \\
\hline $\begin{array}{l}\text { Argaloop } \\
\text { BioFibre }\end{array}$ & $\begin{array}{l}\text { Oil-seed hemp, } \\
\text { oil-seed flax, } \\
\text { pineapple leaves, } \\
\text { banana tree, cane } \\
\text { bagasse, rice } \\
\text { straws }\end{array}$ & $\begin{array}{l}\text { Several } \\
\text { countries }\end{array}$ & $\begin{array}{l}\text { Regenerated cellulose } \\
\text { fibre for knitted and } \\
\text { wovens }\end{array}$ & Lightweight fibre & Fashion, textiles \\
\hline Piñatex & Pineapple leaves & Philippines & $\begin{array}{l}\text { Plant fibre composite } \\
\text { with polylactide (PLA) }\end{array}$ & Leather alternative & $\begin{array}{c}\text { Fashion, accessories, } \\
\text { soft interiors, } \\
\text { automotive }\end{array}$ \\
\hline AppleSkin & Apple pulp & Italy & $\begin{array}{c}\text { Plant cellulose } \\
\text { composite with } \\
\text { polyurethane (PU) for } \\
\text { nonwovens }\end{array}$ & Leather alternative & $\begin{array}{c}\text { Fashion, accessories, } \\
\text { soft interiors, } \\
\text { automotive }\end{array}$ \\
\hline $\begin{array}{l}\text { Vegea Grape } \\
\text { Leather }\end{array}$ & $\begin{array}{l}\text { Grape skins and } \\
\text { stalks }\end{array}$ & Italy & $\begin{array}{c}\text { Plant cellulose } \\
\text { composite with PU for } \\
\text { non-wovens }\end{array}$ & Leather alternative & $\begin{array}{c}\text { Fashion, accessories, } \\
\text { soft interiors, } \\
\text { automotive }\end{array}$ \\
\hline Bananatex & Banana leaves & Philippines & Plant fibre for wovens & $\begin{array}{l}\text { Hardwearing, } \\
\text { durable fibre }\end{array}$ & $\begin{array}{l}\text { Outerwear, travel } \\
\text { accessories, soft } \\
\text { furnishings }\end{array}$ \\
\hline SweetFoam & Sugarcane waste & Brazil & $\begin{array}{l}\text { Poly(ethylene vinyl } \\
\text { acetate) (PEVA) } \\
\text { bioderived copolymer } \\
\text { for foams }\end{array}$ & $\begin{array}{c}\text { Flexible, } \\
\text { impact-absorbing } \\
\text { foam }\end{array}$ & Footwear \\
\hline Chip[s] Board & Potatoes & UK & $\begin{array}{l}\text { Bioplastic for } \\
\text { components }\end{array}$ & $\begin{array}{l}\text { Bioplastic, strong, } \\
\text { rigid }\end{array}$ & $\begin{array}{l}\text { Glasses frames, } \\
\text { buttons, components }\end{array}$ \\
\hline
\end{tabular}

\section{FOOD WASTE STREAMS}

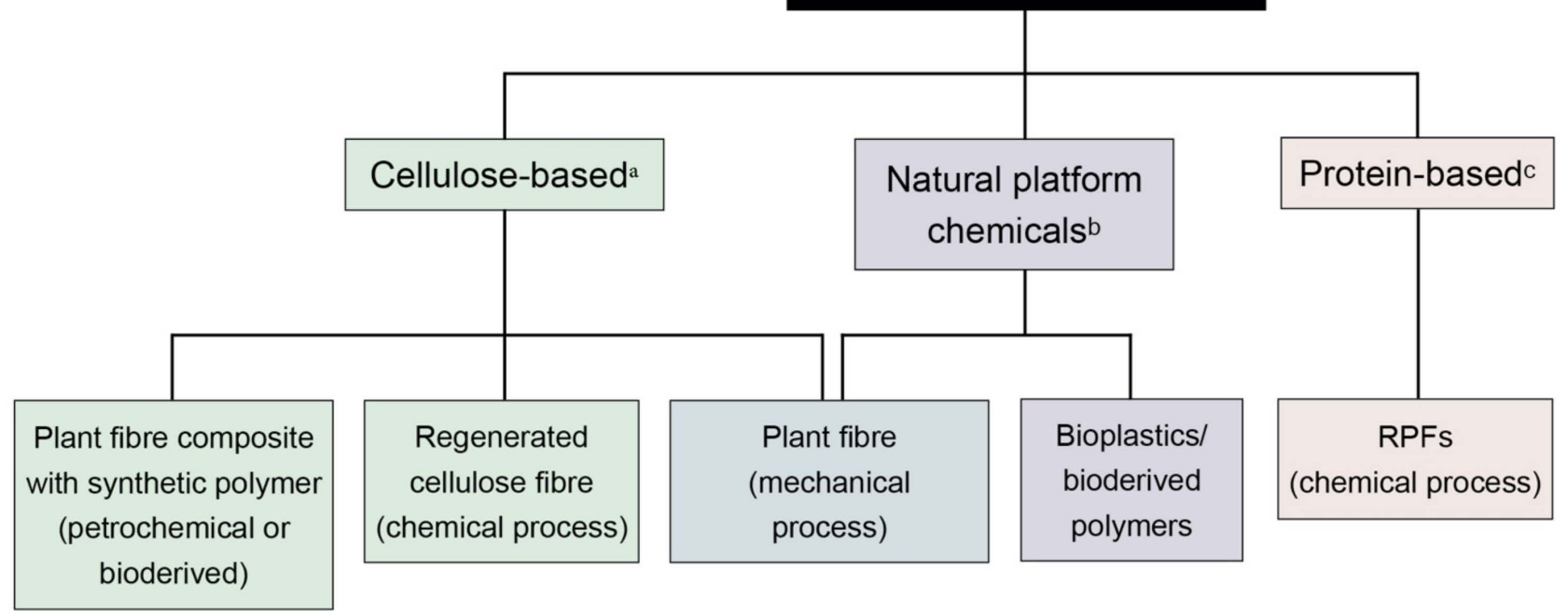

Figure 1. Types of textiles materials from food waste. ${ }^{a}$ Cellulose extracted from plants and used directly (seed or stem fibre) or in regeneration process; ${ }^{b}$ naturally occurring chemicals (e.g., sugar) extracted from a plant source and used in a polymer synthesis process; ${ }^{\mathrm{C}}$ protein extracted from a plant or animal source and used in a regeneration process. 


\subsubsection{Contemporary Food Waste Fibres}

Over the decades, industrialisation has caused the exhaustion of our planet's natural reserves [31]. Humans are now overusing the Earth's biocapacity by at least 56\% [32]. Roughly $33 \%$ of land and $75 \%$ of freshwater resources are allocated to agriculture [33], leading to increased environmental pollution; 300-400 million tonnes of waste (annually) are disposed of in the oceans, creating $70,000 \mathrm{~km}^{2}$ of dead marine areas $[34,35]$. Loss of land and natural habitats will also create extreme global living conditions, increasing the risk of further pandemics caused by the rapid spread of disease between humans and animals [36]. If our current path continues, it is predicted that we will enter a sixth mass extinction (which some argue has already arrived) [37], where millions of species will be lost [34].

In an effort to solve such largescale issues, a circular economy is often employed [38]. A circular economy is a framework for eliminating waste through the continuous use of products and materials [39]. The three common principles of a circular economy are reduce, reuse and recycle [40] and can take many forms within the textile sector, such as clothing swaps, textile recycling or upcycling, all of which keep textile materials in circulation for a longer period of time. In reality, however, we still have a limited understanding of the lifecycle impacts of a circular economy [41] and, as McQuillan [38] points out, "our human-made cycles always leak-either energy or materials or both". Banwell et al. [42] challenge the concept of an infinite recycling loop, stating that non-compostable materials like polyester should be phased out and new fibres, however 'recyclable,' should not be developed if they cannot re-enter the biosphere through composting or degradation. In this context, a new range of bio-based synthetic textiles created from agricultural and/or food industry waste is also beginning to emerge. Table 1 shows a variety of circular, contemporary textiles developed from such waste and highlights the applications of each material. It should be noted that some of these materials are composites with synthetic polymers that are often marketed as being derived from food waste but incorporate polymers that are not food waste derived (e.g., PU, PLA) and that may limit or negate the circularity of such materials.

As the fashion industry races to develop novel solutions to rid itself of its reputation as a polluting force, to be replaced with one that is regenerative, such bio-based fibres are becoming increasingly in demand [43]. Independent designers, luxury fashion, and high street brands alike are investing time and money into tech start-ups or are setting up their own in-house research and development labs to create niche materials. Fast fashion giant H\&M, who has been regularly scrutinised for its wasteful practices and has admitted to burning excess clothing in the past [44], has collaborated with several textile developers to create its Conscious Exclusive Collection. After winning the Global Change Award (GCA) in 2016 (initiated by H\&M), orange fibre is currently in commercial use in H\&M's Conscious Exclusive collection [45] alongside Piñatex, Vegea (winner of the GCA in 2017 [46]) and Argaloop BioFibre (winner of the GCA in 2018 [47]). Other brands within the H\&M Group, including \& Other Stories, COS and Arket, are also using such bio-based fibres to improve the sustainability of their own collections.

\subsubsection{Regenerated Protein Fibres}

The first recorded development of man-made RPFs was in 1894, with Miller producing a fibre called Vanduara silk, made by forcing a concentrated, heated gelatine solution through narrow capillaries to form fine threads [48-50]. The process of wet-spinning RPFs was later pioneered by Todtenhaupt when he developed a method for wet-spinning casein fibres in 1906 [51,52]; this method involved denaturing protein using sodium hydroxide and solubilising it into a viscous spinning 'dope', which was then extruded into an acidified salt coagulation bath to form fibres; this process was refined further by Ferretti in 1937 [53,54]. RPFs found limited use until the advent of WW2 put huge pressure on natural fibre production due to the heavy reliance on wool and silk by the armed forces. The rapid development of spinning methodology is reflected in the majority of some 146 patents 
pertaining to RPFs dated between 1930 and 1950 [55]. Most of the process developments were aimed at improving the functional properties of the resulting fibres. Due to the fact that the concept of 'green chemistry' would not be pioneered by Anastas and Warner until 1998 [56], many of the chemicals and processes used prioritised functionality over waste generation, worker safety and environmental impact. A comprehensive review of the RPF manufacturing practices during the 1940s shows that not only were large quantities of sulphuric acid used in the coagulation baths, but formaldehyde was very commonly used as a hardening agent for the resulting fibres to improve their tensile strength, especially their wet tensile strength; this caused myriad issues revolving around waste treatment and worker safety [10].

There have been several attempts to commercialise RPFs since the wars, with the most recent being German company QMILK having produced a quality, organic RPF from milk waste (casein). This fibre is manufactured through a low input process, which the company claims to be zero-waste and free of hazardous chemicals [57]. Anke Damask, the creator of QMILK, started her own label under the name Mademoiselle Chi Chi in 2011, using her uniquely developed milk fibre in $50 \%$ of her collections [58].

\subsubsection{Textile Supply Chain and Use of Resources}

Due to the urgent need to reduce the environmental burden of the FTI, the increased implementation of a circular economy in manufacturing and business development appears to be a positive move forward. At the same time, there is a significant risk that intensifying the circulation of materials and products in certain parts of the value chain could lead to unexpected outcomes at the system level [41], which could be harmful to the environment and business practices alike.

Alongside the potential environmental benefits associated with materials created from agricultural waste, there are several opposing factors to be considered. These biobased materials are all derived from biomass (or waste) feedstocks; however, there is a concern that as demand for such materials increases, there will be an incentive to harvest first-generation crops for new textiles [43]. The HM Group's involvement with bio-based materials is a prime example of this; although such textiles are currently being used in small collections, H\&M currently offers 12 to 16 collections per year (refreshing them weekly) [59] and, in 2018, had USD 4.3 billion worth of unsold apparel [60]. As the bioeconomy increases and companies such as H\&M expand their sustainable collections, they run the risk of working with less transparent suppliers as well as creating more wastage from unsold clothing. Depending on the initial source of agricultural or industry waste, there is also the risk of the raw material one day running out. This, again, could switch the company's interest towards first-generation bio-based fibres, creating further issues around deforestation and loss of biodiversity.

The biodegradability of materials is another area for consideration. There is a misconception that all biopolymers are biodegradable [43]; however, they often require the correct method of processing at end of life to avoid off-gassing (the release of chemicals into the environment). Additionally, the blending of compostable, bio-based materials with traditional synthetics such as polyester or even natural materials that have been processed using chemicals such as bleach could pose further issues for disposal. Such textile materials would initially have to be separated, requiring further energy and resources [61].

End-of-life aspects such as biodegradability and compostability have been flagged as an area that often lacks transparency within the context of bio-based solutions [27]. The term 'end of life' is often used in the context of a product that is no longer in use by its owner, suggesting that it serves no further purpose [62]. As many of these new materials are still in their infancy, there is little information of their impact upon disposal as well as their potential environmental impact if production is to be scaled up to meet demand. A full lifecycle assessment (LCA) would be required for each new material to determine areas of concern, not just for current production levels but for the future. 
In terms of early RPFs, there is also a gap in information surrounding the full environmental impact throughout the supply chain, from raw material to disposal. As sustainability was not a serious topic of discussion until the launch of the Brundtland report in 1987 [63,64], information such as energy usage, water wastage and impact upon disposal does not exist in the same way. Adding to this, due to the lack of success of RPFs, much of the documentation of their manufacture was destroyed after WW2 due to the embarrassment of a 'failed experiment' [65]. While this lack of information poses a challenge, it also represents an opportunity for research to be performed using the historical precedent set out during the 1940s and 1950s but with a modern, sustainable approach, considering the whole supply chain from waste generation all the way through to end of life.

\subsection{Economic Influences}

During wartime, large amounts of government funding were put into the development of novel RPFs to alleviate pressures on materials such as wool and cotton. Civilian textiles were mostly being used for military uniforms, although the lack of international trade also contributed to shortages around the globe; during WW2, roughly 65\% of the production capacity of the textile industry was devoted to the war effort [66]. Alongside government funding, numerous other tactics were used to control the flow of textiles and limit the public consumption of fashion items. The UK imposed textile rationing in 1941, forcing consumers to become more creative with their limited purchasing power and to adopt a 'make do and mend' attitude in support of the war effort. The experiences and methods of this era can be reflected upon in conjunction with our own current (environmental) crisis and used to address the economic challenges we face today.

In comparison to the WW2 era, today, the fashion market includes many segments and business models, reflecting both the diverse needs of consumers and the growing economies of scale within the industry. By the mid-1970s, fashion brands had begun to copy catwalk styles at much lower cost, supplying cheap fashion products to retail markets within months [67]. This business model expanded rapidly throughout the 1980s and was described by some as the 'democratisation of fashion' [67]. Once exclusive luxuries were now accessible to everyone [68], and whilst clothing had historically represented social class, the wardrobe could now signal other aspects of social identity such as age and gender [69].

In comparison to household incomes, fashion and textile items are much cheaper today compared to just a few decades ago. As the price of clothing has fallen, cheaply made and low-quality fashion dominates the market, allowing consumers to purchase more than is arguably necessary [64]. In the 1950s, 30\% of the household income (UK) went to clothing purchases, and, in 2009, that figure dropped to $12 \%$, but with a larger amount of items being purchased [70]. Today, the average household in the UK spends $3.7 \%$ of its annual income on clothing $[12,71,72]$, yet the number of purchases has still increased due to the decrease in prices.

\subsubsection{Government Incentives for Regenerated Protein Fibres}

During the 1930s and 1940s, RPFs were heavily invested in by several governments as not only a solution to material shortages but also as a way of representing national pride. Italy, before the advent of WW2, was already a powerhouse in the textile world, and the rise of the futurism movement made new and novel materials for fashion very attractive. Ferretti's improvement to the casein spinning process pioneered by Todtenhaupt coincided with the rise of Mussolini in the political leadership in Italy. Mussolini was very keen on Italy achieving economic and commercial self-sufficiency, so he whole-heartedly endorsed Ferretti's process, even to the point that during the war, it was law that all Italian fascist flags had to be made out of Italian made casein fibres (named Lanital, later Merinova) [73]. The Italian military also used casein-based fibres in military uniforms, blankets and boots, believing that it would be resistant to poison gas [74]. 
At the time, Italy was wasting billions of pounds of excess skimmed milk a year so the invention of Lanital was heralded by Mussolini as a key breakthrough, allowing $3.7 \mathrm{~kg}$ of fibre to be produced per $100 \mathrm{~kg}$ of waste milk. Mussolini was so invested in the artificial textiles coming out of SNIA Viscose that the government granted large amounts of money for the continued development and production of Lanital and rayon [75]. The government even issued regulations on the blending of imported fibres with autarchic Italian-made fibres [76]. Many forms of promotional advertising can be seen from around this time, including video documentaries on the production of Lanital and even a poem written by the founder of the Futurist movement, Filippo Tommaso Marinetti, published in pamphlet form and illustrated by Munari, which served to propel Lanital production and popularity [77,78]. The popularity of Lanital took a severe hit after the Italian 1940 campaign in France, where it is thought that rubber-soled Lanital-infused boots caused 2000 cases of frostbite [74].

Italy was not the only country to push for the development and commercialisation of RPFs utilising locally produced waste. A 1940 British patent by Imperial Chemical Industries (ICI) [79] details the production of synthetic fibres from peanuts, which led to the commercialisation of the peanut protein fibre Ardil, so named after the location of the pilot plant (Ardeer in Scotland), between the years of 1951 and 1957 [80]. In the first half of the twentieth century, the UK was still importing 8 million tonnes per annum of peanuts from its colonial territories. The main use for peanuts was the extraction of peanut oil, which left roughly $50 \%$ of the peanut as waste; this was originally used as an animal feed but, through an extraction process, the protein (which represents $\sim 50 \%$ of the residue) [81] could be isolated and used to make fibres for textile usage. ICI developed a method involving the dissolution of the protein in solutions of urea and sodium hydroxide to denature and unfold the globular protein arachin, which could then be wet-spun to form fibres that supposedly had characteristics similar to wool [82]. Similar to other RPFs, the advent of WW2 and the corresponding shortage of wool encouraged investment in the fibre, as well as advert campaigns to try and persuade the British public of the advantages of Ardil; the phrase "Happy families with Ardil" [83] was used during the marketing campaign. Even after the end of hostilities in 1945, ICI was still devoted to Ardil, as seen by the investment of GBP 2.1 million to produce a new manufacturing site in Dumfries [84]. However, the falling price of wool post-war, along with the rise of other artificial fibres and the increasing price of peanuts, put pressure on Ardil as a commodity. The final nail in the coffin was the shortage of peanuts as a result of the failure of the East African peanut scheme [85], which caused the production of Ardil to cease in 1957 [84].

\subsubsection{The Case for a Mixed Economy}

The prevalent fast-fashion paradigm results in an abundance of cheap products in the market [86], placing individual customers in a paradoxical situation. For many reasons, buying long-lasting products can be much more difficult than buying low-quality products [87]. Although there is a growing demand for sustainability in the fashion industry, demand for fast fashion products at fast fashion prices still exists [88].

At present, fast fashion is still a dominant force. Its complete eradication would have huge implications in terms of inclusivity and affordability across different consumer demographics. A study on the sustainable consumption habits of consumers in Spain [89] found that expensive pricing was the second-highest deterrent of purchasing sustainable fashion, with uncertainty of greenwashing being the most common reason. Due to this, it is important to develop sustainable and transparent models for both fast and slow fashion economies, capable of meeting the real needs of consumers.

According to WRAP [90], on average, clothing is used for 3.3 years before it is discarded or passed on, with items such as coats and dresses being kept for the longest. Reports and government action plans appear to favour longevity as the route to sustainability. WRAP's Clothing Longevity Protocol [14] suggests that businesses should employ a "minimum standard of good practice", which should be "embedded across the product 
range, complementing specific design innovations such as anti-fading and anti-pilling technologies and reinforcing brand value by providing a means of quality assurance". There could, however, be various hidden environmental costs to using such additional finishes, including the use of additional chemicals, water, and energy in the manufacturing process. Indeed, if the item is worn on a regular basis and succeeds to reduce the environmental impacts per wear, additional impacts may occur through care and laundering, especially if physical durability has been achieved through coatings or features which require dry cleaning [16].

It could be argued that a shift in cultural mindset must take place before switching to a slow fashion system built for longevity. A McKinsey Company report [91] found that one in three young women in the UK consider garments to be old after just one or two wears. Until consumers adopt 'socially responsible consumption' [92] habits and begin to favour 'better' (for both person and planet) over 'new', a system created for slow fashion alone will surely fail. The question of textile quality also comes into play here. Quality as a term can be interpreted differently across various situations and differ amongst products, people, and places. A product of 'high quality' is often associated with a higher retail value or a 'luxury' market. For a genuinely sustainable slow system to be effective, it must also reflect a variety of price points and be inclusive for all consumer demographics.

\subsection{Cultural Attitudes}

According to Manzini [93], simply redesigning existing products and making ecoefficient improvements to manufacturing processes is not enough to create a more sustainable future. Instead, changes in consumer behaviour and attitudes are needed to stimulate a drastic change in consumption patterns by establishing a connection between individual consumption and the environmental impact of industrial production [64]. Vezzoli [94] argues that radical innovations, beyond technological development, that also stimulate new partnerships between stakeholders as well as new sustainable relationships between consumers and products are needed.

\subsubsection{From Quality to Quantity}

Over the past 50 years, the way in which we produce and consume fashion has changed drastically [10]. Alongside a growing population, excessive seasonal collections [95], low prices [96], discounts and promotional campaigns, the ease of online shopping, and the influence of social media [97] have pushed individual consumption to the limit [31].

As discussed in Section 3.2.2, although consumption has increased, the number of usages has decreased by $36 \%$ compared to just 15 years ago [39]. It is suggested that this reduction in use is not only a result of our temptation to buy new garments but is also a consequence of cheaply made, low-quality garments [64,98-100], which can result in a lack of attachment between product and consumer [31,100].

Quality is a broad term within the FTI and may reflect a range of different attributes, such as how well a product is made, what it is made from, how long it lasts or the way in which it is used or cared for. The Textiles Institute [101] defines quality as "the totality of features and characteristics of a product or service that bears on its ability to satisfy stated or implied needs" or as "a relative term used to indicate the perceived merits of similar products for the same end use." As discovered throughout the literature, the perceived quality of RPFs had a huge impact on their commercial success throughout the early to mid-1900s. For example, garments made from casein were said to be of low strength [84] and difficult to care for due to high moisture absorbency, and the garments would often end up being cut up for rags after just a few wears or washes. Moving into a new era of sustainability, we should question how quality and sustainability might align to meet real consumer needs, whether for a fast or slow circular economy.

Current literature in this area generally tends to associate terms such as 'slow' and 'quality' with sustainability, insinuating that slow equals better when better actually de- 
pends on circumstance and fitness for purpose. This can be defined by a range of performance characteristics, including durability, appearance retention, and ease of cleaning, and some features that are specific to a certain type of product, such as water repellency or flame retardancy [102]. A recent study of sustainability within the fast fashion industry [103] frames product quality as a "vertical attribute that contributes to the lifespan of the product (e.g., quality of stitching, dyeing process, fabric sturdiness)"; the study shows that fast fashion has an incentive to produce multiple styles and 'micro' seasonal collections in response to uncertain and quickly changing trends, and that this is a key driver of low product quality within the industry.

As the availability of trends increases, quality is likely to decrease further as consumers become more responsive to fashion and prioritise style and low prices over durability [103]. Another study into the shopping intentions of young people in Hong Kong and Canada [104] found that the consumers desire for immediate gratification through the purchasing of fashion was one of the main barriers to adopting more sustainable shopping habits. Through its quick turnover of affordable, low-quality styles, the fast fashion model can exploit this segment, offering up-to-date designs and the satisfaction of continually evolving temporary identities [105].

\subsubsection{Challenging Mindsets}

Rissanen [106] believes that the FTI is "still in a mindset of limitless production, mainly made 'possible' by synthetics derived from fossil fuels that are not bound by limits of land use." Although RPFs might offer a technical solution to some of these problems, as discussed, the issue of consumption is not to be forgotten. As we begin to design new systems for the FTI, current behaviours surrounding our relationships with garments must be challenged and redefined within these systems. McQuillan [38] believes that this would require a significant reduction in production and a redistribution of manufacturing locations, creating a connection between product, environment and society.

Although a pertinent issue, cost is only one of the barriers to sustainable consumption. Style, quality, colour, and a continuous desire for the latest trend can all affect consumer purchasing habits [107]. As a result, a growing number of studies are beginning to outline such consumer intentions towards adopting a more sustainable mindset and lifestyle [108]. Bonini and Oppenheim [109] argue that although there is a large amount of awareness surrounding environmental issues, this does not tend to discourage most individuals from overconsuming or purchasing unsustainable products. Joy et al. [104] agree with this claim and, through their own study, show that "fast fashion consumers, often share a concern for environmental issues even as they indulge in consumer patterns antithetical to ecological best practices".

On the other hand, a Unilever study [110] showed that 33\% of adults surveyed (in five EU countries, including the UK) chose to buy from brands they believe are social or environmental responsible; $53 \%$ of shoppers said they feel better when they buy products that are sustainably produced, and $21 \%$ would actively choose brands if they made their sustainability credentials clearer through labelling. Alongside brands and individual consumers, transitioning to a sustainable or circular economy requires genuine collaboration across multiple stakeholders [111]. Niinimäki [64] argues that the most influential way to change such industrial systems towards sustainability is through government, legislation and regulations that directly impact manufacturing requirements.

One of the reasons for the RPFs failing was that they were associated with hardship and substitutions and were largely overshadowed by new and exciting petrochemical-derived fibres such as nylon and polyester, which offered never-before-seen fabric properties of strength, durability and ease-of-care. There was heavy investment from several governments into promoting RPFs to the public, but the negative connotations associated with them was too great. In contrast, the modern consumer's opinion of petrochemical-derived fibres is shifting from the excitement of the 1950s to the 1990s to concern over these fibres and the effect they are having on the environment. This growing dissatisfaction with the 
current state of the fashion and textile industry represents an opportunity for RPFs to return without the negative connotations of the past.

\subsubsection{Matching Textile and Garment Speedcycles}

It is evident that most current circular design approaches favour a 'slow' fashion lifecycle, of which 'quality' garments are built to last using methods such as design for recyclability or design for extended use. The research undertaken by Goldsworthy et al. [16,18] for the Mistra Future Fashion Programme, however, suggests that there is an urgency to also design better 'fast' circular models. As reported by WRAP [112], "extending the life of clothing by an extra nine months of active use would reduce carbon, waste and water footprints by around 20-30\% each." One issue with only focusing on product longevity is that durable (or slow) materials—such as virgin or recycled polyester-often end up being used in fast fashion products with a short life span. As pointed out by McQuillan [38] and Banwell et al. [42], such durable materials are often non-biodegradable and, in the context of polyester, can take at least 200 years to degrade and will leak contaminants back into the ground as they do so. As discussed by Goldsworthy [16], "by reducing our focus to only a 'part' of the system (the use phase), we are playing into the hands of 'unintended consequence' and often simply shifting impacts further along the product lifecycle, albeit out of view."

Perhaps it is the association between fast fashion and poor quality that leads designers and researchers alike to favour a slow fashion lifecycle. On the other hand, fast fashion is popular for a reason, and not everyone can afford to buy into a $100 \%$ slow fashion lifecycle, where products are often more expensive to reflect longevity and durability. In her research of speedcycles, Goldsworthy [16] notes the time taken to produce a raw material in comparison to the length of the use phase. A grown material such as cotton takes a relatively short time to produce (fast) in comparison to a non-renewable material made from oil, which takes thousands of years to form (slow). This provides a contrasting view in comparison to the assumption that natural equals slow (and often better) fashion and that synthetics are for fast fashion. These pre-assumptions of fast or slow are often misleading; if production methods are inconsistent with the expected lifetime of a product, then we are left with an unbalanced lifecycle [16].

In the context of circular textiles and garment speedcycles, appropriate materials need to be developed and selected by designers to be used in fashion products where the duration of use by the owner has been noted and understood [16]. As discussed by Remy et al. [59], "innovation in the way clothes are made has not kept pace with the acceleration of how they are designed and marketed." Fletcher [113] prefers to use the term "slow fashion' in the context of a 'philosophy of attentiveness' as opposed to time and speed. This philosophy is mindful of the needs of its various stakeholders across the supply chain and of the impact producing fashion has on workers, consumers and ecosystems [104].

\section{Discussion}

There is an argument that designing fibres that are intentionally short-lived could provide an alternative to the prescribed slow-fashion solution to the sustainability crisis in fashion. Historical RPFs were designed to provide a 'stop-gap' solution in a time of intense material shortages. During wartime, the aim was not to produce materials that would last a lifetime, as it was hoped that the war effort would be short-lived. This led RPFs to an association with being inferior to the materials they looked to replace. However, within the modern fast fashion movement, clothing is not designed to last a lifetime and is, in fact, designed to last a single season. This might open possibilities to match the fabrics' useful lifespan with the speed at which fashion trends occur; if the fabric only needs to last a few months or even just a few wears, why design it to have the durability and longevity offered by polyester, acrylic, and nylon? Even better, if the material could be designed to degrade without leaching any unwanted chemicals into the soil, there is potential for the circular life cycle of the fabric to be relatively short. Using casein as an example, the 
nitrogen and nutrients from waste milk could be re-introduced into the biosphere through the composting of casein-based textiles. These nutrients could be used in the feed for cows, which would then produce more milk, of which the waste could be converted back into RPFs. A full LCA of the entire process, from conversion into milk via the cows all the way through to the input of the fabric back into the biosphere, would need to be conducted and compared to the current state of the art to ensure that the process is an improvement in relation to sustainability.

Alongside a switch in business attitudes towards fast and slow fashion systems, analysis shows that consumers drive demand for products. Therefore, focusing purely on eco-materials or ethical manufacturing principles misses the opportunity to take a more holistic approach. It could be argued that the sustainable revolution of the fashion and textile industry will begin with consumers changing their purchasing habits, so engaging and educating the public will be crucial in the development of new and novel sustainable solutions.

In the context of disposability, the issues leading to the demise of the RPFs of the 1900s could be seen as advantageous within the modern fashion world. Contrary to the post-war world, public opinion of petrochemically-derived fibres is at an all-time low, with the average consumer now being far more educated on their environmental impact and persistence in the environment at end of life. Along with this, the average time that items of clothing are in use has decreased massively since the 1940s; this means that the issues with the longevity and quality of the RPF fibres are far less of an issue. In fact, designing fabrics that are regenerative via composting and can be re-introduced into the food supply chain within a reasonable timeframe could potentially and synergistically match the current fast fashion trend with the vast amounts of food waste that is generated within the developed world.

Another comparison that can be drawn from the historical investigation of this research is that of a localised economy. During the world wars, the localisation of industry was essential due to the limitations of trade. RPFs were a prime example of this, with different counties adopting different feedstocks depending on their availability within the countries' borders. Post-war, the globalisation of industry gave rise to offshore manufacturing, with the production of feedstocks, processing, and product commercialisation very rarely happening within the same country (or continent), giving rise to vast environmental issues involving the emissions created by shipping and freight. Currently, there is a growing trend away from globalisation, back towards the localisation of industry. The need for this has been further emphasised by the COVID-19 pandemic, with the need for production to be self-sufficient and robust to external factors. Once again, the synergy between the approach taken during the wars to allow for more robust manufacturing and those beginning to be recognised as essential in the modern world to reduce the environmental impact of industry opens an exciting opportunity to learn from the lessons of the past to strive towards a low carbon economy.

While the slowing of the fashion sector is commonly viewed as the necessary breakthrough to creating a sustainable future, this will require a vast change in the cultural mindset of the consumer. As discussed, the solution to the environmental impact of the fashion and textile sector cannot be solved by a single concept but a holistic approach considering the entire sector, from feedstocks and production through to end of life. This will require a collaborative effort from a myriad of sectors, from stakeholder, manufacturing and legislative bodies through to commercial, advertising and government bodies. Most importantly, the consumer must be educated and given the knowledge required to recognise what is truly sustainable.

\section{Conclusions}

The aim of this research was to analyse how RPFs from food industry waste could offer a new perspective on our interpretation of fast and slow speedcycles whilst alleviating pressures on mass consumption. The research also aimed to identify gaps in both the 
historical and contemporary data surrounding the production of RPFs from a sustainability viewpoint, allowing opportunities for further investigation. The major contribution of this study is to critically analyse the academic literature surrounding the implementation of a circular economy within the FTI and a revaluation of 'fast' and 'slow' within the fashion life cycle. In taking a critical and holistic approach to evaluating the principles of a circular economy in the area of bio-based materials and RPFs, it has become clear that the fashion industry is far from creating sustainable change and, in some cases, may do more damage than good. Until we find a successful way to implement holistic system changes and reduce consumption (in a way that is inclusive and attainable for everyone), our efforts in producing novel, eco-friendly materials alone are redundant.

This paper has revealed a gap in academic literature surrounding the end of life of new, bio-based materials and RPFs. Based on this outcome, a full LCA of new generation bio-based materials and RPFs is suggested as the next stage of research. Any future research in this area should also take into consideration the potential of increased consumer demand over time. The concept of a circular economy must also continue to be reviewed with a critical eye, with higher emphasis placed on aspects such as chemical and energy usage, off-gassing, biodegradability and compostability. Consumer-based studies into the appeal of purposely made, disposable fast fashion in comparison to a slow approach is another area of interest for future research. This study has outlined the importance of consumer engagement at all stages of the lifecycle, from design decisions to how garments will be disposed of. Making consumers a part of the decision-making process and adapting marketing content to be informative and educational in terms of sustainability can help to build stronger relationships between stakeholders and begin to drive responsible consumption habits. This research took an interdisciplinary approach to the subject matter and explored the context of materials created from food waste from a range of design, green chemistry, historical and sociological perspectives. However, to continue with this research and create real solutions to such complex problems, further disciplinary boundaries must be crossed. Expertise from areas such as biology, biochemistry, ecology, geography, marketing, and politics should be combined and embedded to create new knowledge in the area of sustainable development across all industries, not limited to the FTI.

Author Contributions: Conceptualisation, M.S., J.A.H., R.S.B. and V.K.; methodology, M.S. and J.A.H.; validation, M.S., J.A.H., R.S.B. and V.K.; formal analysis, M.S. and J.A.H.; investigation, M.S. and J.A.H.; resources, R.S.B. and V.K.; writing—original draft preparation, M.S. and J.A.H.; writing-review and editing, R.S.B. and V.K.; visualisation, M.S. and J.A.H.; supervision, R.S.B. and V.K.; project administration, R.S.B. and V.K.; funding acquisition, R.S.B. and V.K. All authors have read and agreed to the published version of the manuscript.

Funding: This research was funded by the Business of Fashion, Textiles and Technology (www.bf tt.org.uk accessed on 17 November 2019), a Creative R\&D Partnership of the Creative Industries Clusters Programme, funded by the Industrial Strategy and delivered by the Arts and Humanities Research Council on behalf of UK Research and Innovation under grant no. AH/S002804/1.

Conflicts of Interest: The authors declare no conflict of interest.

\section{References}

1. McFall-Johnsen, M. These Facts Show How Unsustainable the Fashion Industry Is. Available online: https://www.weforum.org/ agenda/2020/01/fashion-industry-carbon-unsustainable-environment-pollution/ (accessed on 24 July 2021).

2. UN. Helps Fashion Industry Shift to Low Carbon. Available online: https://unfccc.int/news/un-helps-fashion-industry-shift-to -low-carbon (accessed on 28 July 2021).

3. NNFCC. Future Fashion I-Sustainable Textiles. Available online: https://www.nnfcc.co.uk/news-sustainable-textiles (accessed on 28 July 2021).

4. How Much Do Our Wardrobes Cost to the Environment? Available online: https://www.worldbank.org/en/news/feature/20 19/09/23/ costo-moda-medio-ambiente (accessed on 22 July 2021).

5. Adegeest, D. Wastewater: Fashion's Grotesk Sustainability Problem. Available online: https://fashionunited.uk/news/fashion/ wastewater-fashion-s-grotesk-sustainability-problem/2020050548770 (accessed on 20 July 2021). 
6. Drew, E.R.D. By the Numbers: The Economic, Social and Environmental Impacts of "Fast Fashion". Available online: https: //www.wri.org/insights/numbers-economic-social-and-environmental-impacts-fast-fashion (accessed on 24 July 2021).

7. Milburn, J. The Numbers on Textile Waste. Available online: https:/ / textilebeat.com/the-numbers-on-textile-waste/ (accessed on 24 July 2021).

8. Shirvanimoghaddam, K.; Motamed, B.; Ramakrishna, S.; Naebe, M. Death by waste: Fashion and textile circular economy case. Sci. Total Environ. 2020, 718, 137317. [CrossRef]

9. Spring, A. Landfill Becomes the Latest Fashion Victim in Australia's Throwaway Clothes Culture. Available online: https://www. theguardian.com/fashion/2017/dec/06/landfill-becomes-the-latest-fashion-victim-in-australias-throwaway-clothes-culture (accessed on 26 July 2021).

10. Stenton, M.; Houghton, J.A.; Kapsali, V.; Blackburn, R.S. The Potential for Regenerated Protein Fibres within a Circular Economy: Lessons from the Past Can Inform Sustainable Innovation in the Textiles Industry. Sustainability 2021, 13, 2328. [CrossRef]

11. Preferred Fiber \& Materials Market Report 2020. Available online: https:/ / textileexchange.org/2020-preferred-fiber-and-materia ls-market-report-pfmr-released-2/ (accessed on 10 August 2021).

12. Ütebay, B.; Çelik, P.; Çay, A. Textile Wastes: Status and Perspectives. Available online: https://www.intechopen.com/chapters/ 71971 (accessed on 10 June 2021).

13. Choudhury, A.K.R. Sustainable chemical technologies for textile production. In Sustainable Fibres and Textiles; Woodhead Publishing: Sawston, UK, 2017; pp. 267-322.

14. WRAP. Clothing Longevity Protocol. Available online: http://irep.ntu.ac.uk/id/eprint/29901/1/PubSub7328_Oxborrow.pdf (accessed on 12 June 2021).

15. Fletcher, K.; Tham, M. Clothing rhythms. In Eternally Yours: Time in Design; van Hint, E., Ed.; Rotterdam 010 Publishers: Rotterdam, The Netherlands, 2004; pp. 254-274.

16. Goldsworthy, K. The Speedcycle: A design-led framework for fast and slow circular fashion lifecycles. Des. J. 2017, 20, S1960S1970. [CrossRef]

17. Kendall, S. Design Time, or Wabi Sabi and the Long Now. Available online: http://stuartkendall.com/?p=171 (accessed on 12 June 2021).

18. Goldsworthy, K.; Earley, R.; Politowicz, K. Circular Design Speeds: Prototyping Fast and Slow Sustainable Fashion Concepts through Interdisciplinary Design Research. Available online: https://ualresearchonline.arts.ac.uk/id/eprint/15042/ (accessed on 16 May 2021).

19. Sustainable Development Goals. Available online: https://sdgs.un.org/goals (accessed on 1 August 2021).

20. Transforming Our World: The 2030 Agenda for Sustainable Development. Available online: https:/ / sustainabledevelopment.un. org/post2015/transformingourworld/publication (accessed on 21 July 2021).

21. Sachs, J.; Schmidt-Traub, G.; Kroll, C.; Lafortune, G.; Fuller, G.; Woelm, F. Sustainable Development Report 2020: The Sustainable Development Goals and Covid-19 Includes the SDG Index and Dashboards; Cambridge University Press: Cambridge, UK, 2021.

22. Matharu, A.S.; de Melo, E.M.; Houghton, J.A. Opportunity for high value-added chemicals from food supply chain wastes. Bioresour. Technol. 2016, 215, 123-130. [CrossRef] [PubMed]

23. UNEP. Food Waste Index Report 2021. Available online: https://www.unep.org/resources/report/unep-food-waste-index-repo rt-2021 (accessed on 24 July 2021).

24. The Sustainable Development Goal Report 2020. Available online: Unstats.un.org/sdgs/report/2020/ (accessed on 26 July 2021).

25. WRAP. Food Surplus and Waste in the UK-Key Facts 2020. Available online: https://archive.wrap.org.uk/sites/files/wrap/Fo od-surplus-and-waste-in-the-UK-key-facts-Jan-2020.pdf (accessed on 26 July 2021).

26. WRAP. Food Surplus and Waste in the UK-Key Facts 2021. Available online: https://wrap.org.uk/sites/default/files/2021-06 /Food\%20Surplus\%20and\%20Waste\%20in\%20the\%20UK\%20Key\%20Facts\%20June\%202021.pdf (accessed on 26 July 2021).

27. Lee, S.; Congdon, A.; Parker, G.; Borst, C. Understanding 'Bio' Material Innovations: A Primer for the Fashion Industry. Available online: https: / reports.fashionforgood.com/wp-content/uploads/2020/12/Understanding-Bio-Material-Innovations-Report. pdf (accessed on 6 May 2021).

28. European Committee for Standardisation, Biobased Products. Available online: https://www.cen.eu/work/areas/chemical/bio based/Pages/default.aspx (accessed on 15 July 2021).

29. Orange Fiber. Available online: http:/ / orangefiber.co/ (accessed on 2 April 2020).

30. Pinatex. Available online: https:/ / www.ananas-anam.com/ (accessed on 2 April 2021).

31. Ciornea, R. Is the Transition to Bioeconomy a Sustainable Solution in Fast-fashion Industry, Considering the Overconsumption?Premises for Future Research. Mark. Inf. Decis. J. 2020, 3, 27-44. [CrossRef]

32. Almond, R.; Grooten, M.; Petersen, T. Living Planet Report 2020-Bending the Curve of Biodiversity Loss: A Deep Dive into Freshwater. Available online: https:/ / www.zsl.org/sites/default/files/LPR\%202020\%20Full\%20report.pdf (accessed on 6 June 2021).

33. UN. Report: Nature's Dangerous Decline 'Unprecedented'; Species Extinction Rates 'Accelerating'. Available online: https: //www.un.org/sustainabledevelopment/blog/2019/05/nature-decline-unprecedented-report/ (accessed on 2 March 2021).

34. Bongaarts, J. IPBES, 2019. Summary for policymakers of the global assessment report on biodiversity and ecosystem services of the Intergovernmental Science-Policy Platform on Biodiversity and Ecosystem Services. Popul. Dev. Rev. 2019, 45, 680-681. [CrossRef] 
35. Sarkar, S.K. Marine Algal Bloom: Characteristics, Causes and Climate Change Impacts; Springer: Berlin/Heidelberg, Germany, 2018.

36. Settele, J.; Diaz, S.; Brondizio, E.; Daszak, P. COVID-19 Stimulus Measures Must Save Lives, Protect Livelihoods, and Safeguard Nature to Reduce the Risk of Future Pandemics. Available online: https:/ /ipbes.net/covid19stimulus (accessed on 4 May 2021).

37. Barnosky, A.D.; Matzke, N.; Tomiya, S.; Wogan, G.O.; Swartz, B.; Quental, T.B.; Marshall, C.; McGuire, J.L.; Lindsey, E.L.; Maguire, K.C. Has the Earth's sixth mass extinction already arrived? Nature 2011, 471, 51-57. [CrossRef] [PubMed]

38. McQuillan, H. Zero Waste Systems Thinking: Multimorphic Textile-Forms. Ph.D. Thesis, Högskolan i Borås, Borås, Sweden, 2020.

39. A New Textiles Economy: Redesigning Fashion's Future. Available online: https://www.ellenmacarthurfoundation.org/assets/ downloads / publications / A-New-Textiles-Economy_Full-Report.pdf (accessed on 12 July 2021).

40. Ghisellini, P.; Cialani, C.; Ulgiati, S. A review on circular economy: The expected transition to a balanced interplay of environmental and economic systems. J. Clean. Prod. 2016, 114, 11-32. [CrossRef]

41. Levänen, J.; Uusitalo, V.; Härri, A.; Kareinen, E.; Linnanen, L. Innovative recycling or extended use? Comparing the global warming potential of different ownership and end-of-life scenarios for textiles. Environ. Res. Lett. 2021, 16, 054069. [CrossRef]

42. Banwell, E.; Schuknecht, M.; Rattner, B.; Hulst, N.; Dougherty, B. The Nature of Fashion. Available online: https:/ /bioplasticsn ews.com/wp-content/uploads/2020/07/The-Nature-of-Fashion.pdf (accessed on 4 May 2021).

43. Chen, T. The Magic Formula Behind Food Waste-Based Textiles. Available online: https://www.commonobjective.co/article/the -magic-forumula-behind-food-waste-based-textiles (accessed on 13 July 2021).

44. Brooke, E. H\&M Denies Burning Good, Unsold Product. Available online: https:/ /www.racked.com/2017/10/20/16510512/h m-burning-clothing (accessed on 13 May 2021).

45. Orange Fiber. Available online: https://hmgroup.com/our-stories/orange-fiber/ (accessed on 13 May 2021).

46. Grape Leather. Available online: https://globalchangeaward.com/winners/grape-leather/ (accessed on 15 August 2020).

47. Circular systems. Available online: https://hmfoundation.com/gca/winners/circular-systems/ (accessed on 15 August 2020).

48. Cash, J.; Greener, T. J. Soc. Arts, 1899; 48, 61-72.

49. Traill, D. Protein synthetic fibres. J. Text. Inst. Proc. 1946, 37, P295-P301. [CrossRef]

50. Millar, A. A New or Improved Manufacture of Fibres or Filaments Suitable for Making Textile Fabrics. GB189415522A, 15 June 1985.

51. Todtenhaupt, F. Production of Artificial Silk and Artificial Hair from Casein. U.S. Patent 836788, 27 November 1906.

52. Wormell, R.L. New Fibres from Proteins; Academic Press: Cambridge, MA, USA, 1954.

53. Ferretti, A. Improvements in or Relating to the Manufacture of Artificial Textile Fibres. GB483731A, 21 April 1938.

54. Artificial Wool Production in Italy. Nature 1937, 140, 1090. [CrossRef]

55. Brooks, M.M. Substitute Innovation: Rethinking the Failure of Mid-Twentieth Century Regenerated Protein Fibres and their Legacy. In Proceedings of the Textile Society of America Symposium, Los Angeles, CA, USA, 10-14 September 2014.

56. Anastas, P.T.; Warner, J.C. Green chemistry. Frontiers 1998, 640, 1998.

57. WRAP. Fashioning Waste Milk into Fibres. Available online: http://www.wrap.org.uk/sites/files/wrap/QMilk-Fashioning\%2 0waste\%20milk\%20into\%20fibres.pdf (accessed on 19 April 2021).

58. Madomoiselle Chi Chi. Available online: http://www.ecofashiontalk.com/resource/madomoiselle-chi-chi/ (accessed on 15 July 2020).

59. Remy, N.; Speelman, E.; Swartz, S. Style That's Sustainable: A New Fast-Fashion Formula. Available online: https://search.pro quest.com/docview/2372072480 (accessed on 15 July 2021).

60. Sachs, J. Can H\&M's Sustainable Clothing Line Make Up For The Damage Fast Fashion Has Already Caused? Available online: https:/ / gritdaily.com/fast-fashion-sustainable/ (accessed on 4 May 2021).

61. Šajn, N. Environmental Impact of the Textile and Clothing Industry. Available online: https://www.europarl.europa.eu/RegDa ta/etudes/BRIE/2019/633143/EPRS_BRI (accessed on 16 August 2021).

62. Towards the Circular Economy Vol. 1: An Economic and Business Rationale for an Accelerated Transition. Available online: https: / / www.ellenmacarthurfoundation.org/assets/downloads/publications/Ellen-MacArthur-Foundation-Towardsthe-Circular-Economy-vol.1.pdf (accessed on 15 July 2021).

63. Brundtland, G. Report of the World Commission on Environment and Development: Our Common Future. Available online: http:/ / www.ask-force.org/web/Sustainability/Brundtland-Our-Common-Future-1987-2008.pdf (accessed on 28 July 2021).

64. Niinimäki, K. From Disposable to Sustainable The Complex Interplay between Design and Consumption of Textiles and Clothing. Ph.D. Thesis, Aalto University, Espoo, Finland, 2011.

65. Brooks, M.M.; Rose, M. Contextualizing Textiles: Using Documentary Evidence to Retrieve Evidence for Regenerated Protein Fibres. Stud. Conserv. 2006, 51, 82-88. [CrossRef]

66. Heard, E. Wartime Developments in Textiles and Clothing. J. Home Econ. 1942, 34, 427-432.

67. Siegle, L. Fast Fashion is on the Rampage, with the UK at the Head of the Charge. Available online: https:/ / www.theguardian.co $\mathrm{m} /$ fashion/2019/jun/21/fast-fashion-is-on-the-rampage-with-uk-at-the-head-of-the-charge (accessed on 15 May 2021).

68. Zhang, B.; Zhang, Y.; Zhou, P. Consumer attitude towards sustainability of fast fashion products in the UK. Sustainability 2021, 13, 1646. [CrossRef] 
69. Crane, D. Fashion and Its Social Agendas: Class, Gender, and Identity in Clothing; University of Chicago Press: Chicago, IL, USA, 2012.

70. Jackson, T.; Shaw, D. Mastering Fashion Marketing; Palgrave Macmillan: Hampshire, UK, 2009.

71. Yurday, E. Here's How Much You Should Spend on Clothing Each Month. Available online: https://www.nimblefins.co.uk/here s-how-much-you-should-spend-clothing-each-month (accessed on 22 July 2021).

72. Family Spending in the UK: April 2019 to March 2020. Available online: https://www.ons.gov.uk/peoplepopulationandcomm unity/personalandhouseholdfinances/expenditure/bulletins/familyspendingintheuk/april2019tomarch2020 (accessed on 22 July 2021).

73. Wear More Milk—The Children's Newspaper. Available online: https://archive.org/details/The_Childrens_Newspaper_0941_1 937-04-03/page/n3/mode/2up (accessed on 5 May 2021).

74. Maxwell, A. Patriots Against Fashion: Clothing and Nationalism in Europe's Age of Revolutions; Springer: Berlin/Heidelberg, Germany, 2014.

75. Waters, M. How Clothing Made from Milk Became the Height of Fashion in Mussolini's Italy. Available online: https://www.at lasobscura.com/articles/lanital-milk-dress-qmilch (accessed on 23 November 2019).

76. Battista, A. Return of the 'Milk Dress'. Available online: https://www.irenebrination.com/irenebrination_notes_on_a/2011/05/1 anital-avh.html (accessed on 28 May 2021).

77. Marinetti, F.T. Il Poema del Vestito di Latte: Parole in Libertà Futuriste (The Poem of the Dress of Milk: Futurist Words in Freedom). Available online: https:/ / digital.wolfsonian.org/WOLF049395/00001/1j (accessed on 1 March 2020).

78. La Lavorazione Autarchica per Estrarre la Lana Dal Latte. Available online: https://artsandculture.google.com/asset/la-lavoraz ione-autarchica-per-estrarre-la-lana-dal-latte/NQH1lKEhME2uFA (accessed on 10 October 2020).

79. Traill, D.; Seddon, R.V.; Sever, W. Manufacture of Artificial Fibres from Protein Material. GB524090A, 30 July 1940.

80. Ardil-Conservation and Arts Materials Encyclopedia Online (CAMEO). Available online: http://cameo.mfa.org/wiki/Ardil (accessed on 3 April 2021).

81. Heuzé, V.; Thiollet, H.; Tran, G.; Bastianelli, D.; Lebas, F. Peanut Meal. Available online: https://www.feedipedia.org/node/699 (accessed on 7 July 2021).

82. Mahapatra, N.N. Groundnut Protein Fiber, Its Properties, and End Use. Available online: https://www.textiletoday.com.bd/gr oundnut-protein-fiber-properties-end-use/ (accessed on 21 May 2021).

83. Hall, K.T. The Man in the Monkeynut Coat: William Astbury and the Forgotten Road to the Double-Helix; OUP Oxford: Oxford, UK, 2014.

84. Cook, J.G. Handbook of Textile Fibres: Man-Made Fibres; Elsevier: Amsterdam, The Netherlands, 1984.

85. Edgerton, D. The Rise and Fall of the British Nation: A Twentieth-Century History; Penguin: London, UK, 2018.

86. Niinimäki, K.; Peters, G.; Dahlbo, H.; Perry, P.; Rissanen, T.; Gwilt, A. The environmental price of fast fashion. Nat. Rev. Earth Environ. 2020, 1, 189-200. [CrossRef]

87. Van Loon, P.; Delagarde, C.; Van Wassenhove, L.N. The role of second-hand markets in circular business: A simple model for leasing versus selling consumer products. Int. J. Prod. Res. 2018, 56, 960-973. [CrossRef]

88. Lindén, A. Is Green the New Black?: An Investigation of Underlying Factors That May Influence Generation Y Consumers' Purchase Behaviour of Sustainably Produced Clothes. Available online: https://explore.openaire.eu/search/publication?article $\mathrm{Id}=$ od__ 264::9cbb8be45529764476054a3bc592f325 (accessed on 21 May 2021).

89. Riesgo, S.B.; Lavanga, M.; Codina, M. The consumption side of sustainable fashion: Price sensitivity, value and transparency demand. In Proceedings of the Global Fashion Conference 2020, Lyon, France, 21-23 October 2020.

90. WRAP. Valuing Our Clothes: The Cost of UK Fashion. Available online: https://wrap.org.uk/sites/default/files/2020-10/WRA P-valuing-our-clothes-the-cost-of-uk-fashion_WRAP.pdf (accessed on 20 June 2021).

91. The State of Fashion 2019. Available online: https://cdn.businessoffashion.com/reports/The_State_of_Fashion_2019.pdf (accessed on 15 May 2021).

92. Jermsittiparsert, K.; Siam, M.; Issa, M.; Ahmed, U.; Pahi, M. Do consumers expect companies to be socially responsible? The impact of corporate social responsibility on buying behavior. Uncertain Supply Chain. Manag. 2019, 7, 741-752. [CrossRef]

93. Manzini, E. Design, Environment and Social Quality: From “Existenzminimum" to “Quality Maximum”. Des. Issues 1994, 10, 37-43. [CrossRef]

94. Vezzoli, C.A. System Design for Sustainability. Theory, Methods and Tools for a Sustainable "Satisfaction-System" Design; Maggioli: Rome, Italy, 2007.

95. Webster, K. Fusion of Artisan and Virtual: Fashion's New World Opportunities. In Handbook of Research on Global Fashion Management and Merchandising; IGI Global: Pennsylvania, PA, USA, 2016; pp. 346-372.

96. Bick, R.; Halsey, E.; Ekenga, C.C. The global environmental injustice of fast fashion. Environ. Health 2018, 17, 1-4. [CrossRef] [PubMed]

97. Fixing Fashion: Clothing Consumption and Sustainability. Available online: https://publications.parliament.uk/pa/cm201719/c mselect/cmenvaud/1952/report-summary.html (accessed on 18 July 2021).

98. Yoon, N.; Lee, H.K.; Choo, H.J. Fast Fashion Avoidance Beliefs and Anti-Consumption Behaviors: The Cases of Korea and Spain. Sustainability 2020, 12, 6907. [CrossRef] 
99. Dissanayake, D. Does Mass Customization Enable Sustainability in the Fashion Industry. In Fashion Industry-An Itinerary between Feelings and Technology; Belatramo, R., Romani, A., Cantore, P., Eds.; IntechOpen: London, UK, 2019; pp. 21-32.

100. Fletcher, K. Durability, fashion, sustainability: The processes and practices of use. Fash. Pract. 2012, 4, 221-238. [CrossRef]

101. Denton, M.J.; Daniels, P.N. Textile Terms and Definitions, 11th ed.; Textile Institute: Manchester, UK, 2002.

102. Taylor, M. Technology of Textile Properties, 3rd ed.; Forbes Publications: Jersey City, NJ, USA, 1993.

103. Long, X.; Nasiry, J. Sustainability in the Fast Fashion Industry. Available at SSRN 3486502. Available online: https:/ / papers.ssrn. com/sol3 / papers.cfm?abstract_id=3486502\&download=yes (accessed on 15 June 2021).

104. Joy, A.; Sherry, J.F., Jr.; Venkatesh, A.; Wang, J.; Chan, R. Fast fashion, sustainability, and the ethical appeal of luxury brands. Fash. Theory 2012, 16, 273-295. [CrossRef]

105. Bauman, Z. Liquid Life, 1st ed.; Polity: Cambridge, UK, 2005.

106. Rissanen, T. Land As a Defining Limit for Fashion Production. Available online: https://timorissanen.wordpress.com/2020/08 /02/land-as-a-defining-limit-for-fashion-production/ (accessed on 6 February 2021).

107. Niinimäki, K. Eco-clothing, consumer identity and ideology. Sustain. Dev. 2010, 18, 150-162. [CrossRef]

108. Ciasullo, M.V.; Maione, G.; Torre, C.; Troisi, O. What about sustainability? An empirical analysis of consumers' purchasing behavior in fashion context. Sustainability 2017, 9, 1617. [CrossRef]

109. Bonini, S.; Oppenheim, J. Cultivating the Green Consumer. Available online: https://search.proquest.com/docview/217174224 (accessed on 6 June 2021).

110. Report Shows a Third of Consumers Prefer Sustainable Brands. Available online: https://www.unilever.com/news/press-releas es / 2017 / report-shows-a-third-of-consumers-prefer-sustainable-brands.html (accessed on 28 May 2021).

111. Hazen, B.T.; Mollenkopf, D.A.; Wang, Y. Remanufacturing for the Circular Economy: An Examination of Consumer Switching Behavior. Bus. Strategy Environ. 2017, 26, 451-464. [CrossRef]

112. WRAP. Valuing Our Clothes: The True Cost of How We Design, Use and Dispose of Clothing in the UK; WRAP: Banbury, UK, 2012.

113. Flechter, K. Sustainable Fashion and Textiles-Design Journeys; Earthscan: London, UK, 2008. 